\title{
Potret Islam dalam Bingkai Kearifan Lokal: Studi Makna Arsitektur Kampung Naga
}

\author{
Muhammad Alifuddin \\ Fakultas Syari'ah Institut Agama Islam Negeri Kendari \\ proposalalif@gmail.com
}

\begin{abstract}
This research aims to describe the form and meaning of house in Naga in term of emic and ethic perspectives. This study focuses on the form and space of house arcithecture as well as the symbolic meaning of house for people living in Naga. The data is generated through a series of interview, participant observation and library research. The research shows that the form of Naga's house is closely related to their belief in which the world is divided into three, i.e: upper world, middle and the lower one. In addition, that form also reflects their views on the place of men and women within the house. Though separation is required by their tradition, they also provide the neutral room in which male and female could meet together. Their houses also provide the sacred room to reflect the existencse of God within their life. To sum up, those beliefs are, to some extent, in line with the Islamic norms practiced by Muslim in their daily life. Basically, symbols in the house contain universal symbol, except for goah which is believed as Dewi Sri's room. However, the house's design, form, and arrangement are quite similar to Islamic architecture with some restrictions states as Islamic portrait within local wisdom framework.
\end{abstract}

\section{Key Words: Islam, Local tradition, Kampung Naga Architecture}

\begin{abstract}
Abstrak
Penelitian ini bertujuan mendeskripsikan bentuk dan makna rumah Orang Naga, baik dalam perspektif emik maupun etik dengan fokus pada bagaimana bentuk dan ruang arsitektur rumah Orang Naga, dan aspek simbolis serta makna arsiektur rumah tersebut bagi orang Naga. Sumber data penelitian diperoleh melalui wawancara, observasi partisipasif dan studi dokumen. Temuan penelitian ini menunjukan bahwa bentuk rumah Naga memiliki makna estetika yang terkait dengan kepercayaan adanya dunia atas, dunia tengah dan dunia bawah. Bentuk komposisi ruang Rumah Naga masih dipercaya untuk penempatan ruang perempuan dan laki-laki, selain terdapat ruang netral dan ruang sakral. Dalam perkembangan selanjutnya tampak ada upaya dari internal orang Naga untuk memberi pespektif baru dalam memaknai Rumah Naga, yang mengarah pada intrepretasi yang berorientasi pada nilai-nilai Islam. Kumpulan simbol yang tertanam dalam Rumah Naga, pada prinsipnya memiliki nilai-nilai universal, kecuali simbolisasi goah yang dipercayai sebagai ruang Dewi Sri. Namun dalam banyak hal, desain bentuk dan tata ruang Rumah Naga memiliki kesesuaian dengan nilai arsitektur Islam, sehingga Rumah Naga dalam
\end{abstract}


batas-batas tertentu dapat dinyatakan sebagai potret Islam dalam bingkai kearifan lokal.

Kata Kunci: Islam, tradisi lokal, arsitektur kampung Naga.

\section{A. PENDAHULUAN}

Secara umum arsitektur yang hidup dalam suatu komunitas memiliki kaitan yang erat dengan tradisi dan pandangan hidup masyarakat setempat. ${ }^{1}$ Sebuah karya arsitektur mengkomunikasikan kondisi masyarakat di mana artefak tersebut berada. Artefak merupakan wujud akhir yang timbul akibat adanya gagasan dan tindakan dalam suatu kebudayaan. ${ }^{2}$ Oleh karena itu, tidak ada pengingkaran tentang pentingnya makna dalam sebuah wujud bangunan yang dihasilkan dari gagasan yang berbasis pada tradisi suatu masyarakat. Dalam konteks tersebut, maka menjadi niscaya untuk menkaji secara mendalam pandangan masyarakat mengenai disain arsitektur sebuah bangunan yang tumbuh dalam ruang sejarah dan budaya sebuah komunitas. Berangkat dari dasar pemikiran tersebut, maka pertanyaan mendasar dalam penelitian ini adalah bagaimana pandangan Orang Kampung Naga tentang disain arsitektur rumah yang hidup dalam ruang sejarah dan kebudayaan mereka? Berdasarkan masalah di atas maka sejumlah masalah yang akan diretas dalam penelitian ini adalah 1) bagaimana bentuk dan tata ruang rumah dalam masyarakat Kampung Naga? 2) apa makna rumah Kampung Naga bagi masyarakat setempat? 3) aspek simbolik apa yang terkandung dalam arsitektur rumah tradisional Kampung Naga?

Telah banyak kajian yang dilakukan oleh para peneliti terkait dengan studi arsitektur Sunda. Studi tentang arsitektur dan tata ruang secara umum dilakukan oleh Wiranto dengan judul "Arsitektur Vernakular Indonesia: Perannya Dalam Pengembangan Jati Diri”. Ade Sahroni melakukan penelitian tentang "Arsitektur Vernakular Indonesia: Peran, Fungsi, Dan Pelestarian Di Dalam Masyarakat"; Maria I Hidayatun melakukan studi tentang "Hakekat Ruang Dalam Arsitektur Tradisional Sebagai Satu Bentuk Jawaban Dari Tatangan Alam (Studi Tentang Arsitektur Tradisional Vernakular" Penelitian lain yang serupa dilakukan oleh Yophie Septiady dan Shinta Dewi Mahara dengan judul "Keterkaitan Ilmu Sosial Terhadap Keberadaan Ruang Arsitektural"; Ni Ketut Agusinta Dewi dengan judul

${ }^{1}$ Barliana, Syaom, 2008, "Perkembangan Arsitektur Mesjid: Suatu Transformasi Bentuk dan Ruang", Jurnal Historia, Vol IX, No.2, (Desembar, 2008).

${ }^{2}$ Koentjaraningrat, Pokok-Pokok Antropologi Sosial, (Jakarta: Dian Press, 1985), h. 74 
"Wantah Geometri, Simetri, Dan Religiusitas Pada Rumah Tinggal Tradisional Di Indonesia”. Studi tentang tata ruang arsitektur yang menyasar pada kebudayaan tradisional Indonesia, khususnya masyarakat Sunda sebagaimana yang dilakukan Jamaludin dengan judul "Memahami Desain dan Arsitektur Tradisional Sunda"; Martinus Deny dengan judul "Rumah Tradisional Sunda Dalam Perspektif Teori Paradoks "; Nuryanto, dan Isep Machpudin dengan judul "Kajian Pola Kampung dan Rumah Tinggal Warga Kasepuhan Kesatuan Adat Banten Kidul di Sukabumi Selatan-Jawa Barat"; Saringendyanti dengan judul "Kampung Naga Tasikmalaya Dalam Mitologi: Upaya Memaknai Warisan Budaya Sunda”; Agung Wahyudi dengan judul "Perancangan Bangunan Tradisional Sunda sebagai Pendekatan Kearifan Lokal, Ramah Lingkungan dan Hemat Energi"; Indira Kusama Dewi dan Priono Sujuono dengan berjudul "Penggambaran dalam Sistem terhadap Faktor-Faktor Penentu Emisi $\mathrm{CO}_{2}$ pada Pembangunan Rumah dan Kehidupan di Kampung Naga"; Redaksi Jurnal Tata Ruang dengan judul "Karakteristik Ruang dan Konstruksi Bangunan Kampung Naga”.

Dari sejumlah studi yang dipaparkan tentang bangunan tradisional hanya ada tiga tulisan yang secara khusus mengkaji obyek bangunan yang berada di kampung Naga yaitu kajian Agung Wahyudi, Indira Kusama Dewi dan Priono Sujuono, serta redaksi Tata Ruang. Studi yang dilakukan oleh Wahyudi adalah disain penelitian yang menitikberatkan pada pendekatan rancang bangun dengan pendekatan yang berbasis pada ilmu-ilmu keteknikan. Pendekatan yang sama juga tampak pada rilis Jurnal Tata Ruang. Sedangkan tulisan Dewi dan Sujiono, memilih kajian pendekatan tata ruang yang berbasis pada studi ilmu lingkungan. Ketiga penelitian di atas sungguhpun merupakan kajian tentang Kampung Naga, namun pendekatan yang digunakan tidak berada pada alur kajian antropologi dengan basis pendekatan ethnografi.

Tulisan ini menggunakan metode etnografi yang berbasis pada datadata kualitatif. Sumber data penelitian diperoleh melalui serangkain wawancara, observasi partisipasif dan studi dokumen. Sebagai upaya untuk menangkap irama dan cara berpikir atau pola kerja sitem budaya, maka dalam konteks ini, peneliti dirangsang untuk mengkaji banyak detail dan menempatkan dirinya dalam pengertian hadir disana (being there) baik secara intelektual maupun emosional. Metode ini oleh Geertz disebut thick description atau biasa juga disebut dengan anthropology interpretative. Datadata yang terkumpul dianalisis melalui tahapan perumusan pertanyaan 
penelitian, membuat narasi yang bersifat deskriptif, reduksi data, eksplikasi dan interpretasi, dan mengambil kesimpulan.

\section{B. KONSEP BENTUK, RUANG, DAN MAKNA ARSITEKTUR 1. Konsep Bentuk}

Bentuk adalah suatu perwujudan dari organisasi ruang yang merupakan hasil dari suatu proses pemikiran. Proses ini didasarkan atas pertimbangan fungsi dan usaha pernyataan diri/ekspresi. Eppi, dkk menguraikan bahwa bentuk-bentuk arsitektur memiliki unsur-unsur garis, lapisan, volume, tekstur, dan warna. Kombinasi atau perpaduan dari kesemua unsur akan menghasilkan ekspresi bangunan. Ini menghasilkan suatu pengungkapan maksud dan tujuan bangunan secara menyeluruh. ${ }^{3}$ Dengan melalui uraian tersebut di atas dapat dipahami bahwa kondisi fisik bentuk menentukan ekspresi bangunan, menghasilkan citra tertentu yang merupakan aspek filosofis desain yang menentukan kekhasan desain. Dengan demikian, bentuk memiliki peran mendasar dalam setiap keputusan pada proses perancangan arsitektur.

\section{Konsep Ruang}

Dalam pengertian matematis, ruang dimengerti sebagai keberadaan fisik dimensional yang dapat diukur secara matematis isinya karena pembungkusnya yang memiliki panjang, lebar dan tinggi. Dalam dunia arsitektur, ruang tidak hanya dipahami dari segi matematisnya saja, namun ruang dapat juga dirasakan, dihayati, dan diselami. Dalam arsitektur, ruang memiliki jiwa sehingga ruang memepengaruhi keberadaan individu atau manusia yang berada di dalamnya. Ruang merupakan interaksi antara jiwa ruang secara fisik dan metafisik dengan batin manusia yang terlibat dalam eksistensinya. ${ }^{4}$

\section{Konsep Makna}

Makna atau dalam bahasa inggris "meaning", berasal dari bahasa Jerman "meinen", yang menunjuk pada pengertian "ada di pikiran atau benar". ${ }^{5}$ Makna adalah tanda linguistic, yang tiap tanda terdiri atas dua unsur, yang diartikan (unsur makna) dan yang mengartikan (unsur bunyi). Keduanya disebut sebagai intralingual dan merujuk pada suatu referens (seperti maksud) yang merupakan unsur ekstralingual. Dan pada umumnya, kata memiliki makna majemuk. Setiap kata memiliki makna denotatif, yaitu makna yang tidak mengandung arti tambahan, dan makna konotatif, yaitu makna yang mengandung arti tambahan, perasaan tertentu, atau nilai rasa tertentu di

${ }^{3}$ Eppy, Estetika Bentuk, (Jakarta: Gunadarma, 1986), h. 52-53

${ }^{4}$ Ibid

5 Raharjo, Mudjia, Dasar-Dasar Hermeneutika antara Intersionalisme dan Gadamerian, (Ar-Ruzmedia: Yogjakarta, 2008), h. 73. 
samping makna dasar yang umum. Itu sebabnya makna sebuah teks bisa lebih luas dari pada maksud penulis sekalipun. Sebab, tafsir atas teks nyaris tidak terbatas dan tidak sepenuhnya bisa dikontrol oleh si penulis sendiri. Bahkan, Ricoeur menegaskan, maksud si penulis pun bukan satu-satunya tafsir terbaik. $^{6}$

\section{MAKNA RUMAH BAGI ORANG NAGA}

Orang Naga memandang rumah sebagai tempat bernaung atau berlindung dari panas dan hujan, sebagai tempat bercengkrama bersama keluarga, mendidik anak, menenangkan diri atau beristirahat, juga sebagai bentuk pengejawantahan nilai-nilai budaya yang diwariskan oleh leluhur. Namun demikian, untuk menelaah secara lebih mendalam tentang rumah sebagai sebuah "simbol", maka penting kiranya untuk menguraikan beberapa aspek filosofi rumah berdasarkan data fenomenologis yang disaksikan di lapangan.

Orang Sunda termasuk di dalamnya orang Kampung Naga menyebut rumah dengan kata "imah". Rumah atau imah telah menjadi wadah kegiatan sehari-hari sejak bangun tidur menyongsong fajar hingga kembali ke peraduan di malam hari. Rumah juga merupakan saksi kehidupan penghuninya sejak lahir hingga wafat. Selain "imah", rumah juga dibahasakan oleh mereka dengan kata "bumi". Secara eksplisit bahasa Sunda halus untuk rumah disebut dengan "bumi", jagat alam yang mewadahi berbagai kehidupan di dalamnya termasuk manusia, sehingga rumah bukan sekedar bangunan belaka. Jamaluddin menjelaskan bahwa bagi orang Sunda memandang rumah bagaikan "bumi" yang menunjukkan kejelasan visi dari arsitektur etnik atau tradisional Kampung Naga. Hal ini berbeda dengan visi yang mendasari desain karya arsitek yang menonjolkan nilai artistik individualistik seperti yang berkembang pada era modern dewasa ini, dimana memandang desain arsitektural semata-mata sebagai sebuah ungkapan cita rasa keindahan. Sedangkan arsitektur vernacular atau tradisional oleh pemiliknya bukan hanya sebagai ungkapan arsitektural, namun vernekularisme adalah sebuah ungkapan terhadap unsur simbolik dibalik raga sebuah bangunan.

Menyebut rumah dengan kata "bumi”, nampak jelas kalau orang Naga memandang rumah bukan hanya sebagai tempat tinggal, tetapi juga merupakan personifikasi dari penciptaan dunia. Dalam konteks tersebut, rumah dipandang sebagai penghubung sekaligus pemisah antara makrokosmos dan mikrokosmos, antara manusia dan pencipta-Nya. Dalam konteks perwujudan arsitektural, maka bentukan rumah Naga, bagi orang

${ }^{6}$ Ibid., h. 58 
Naga adalah wujud dari ekspresi sekaligus apsresiasi mereka terhadap budaya leluhurnya, bukan saja yang menyangkut fisik bangunannya, tetapi juga semangat dan jiwa yang terkandung di dalamnya. Pemaknaan kata "bumi" sebagai rumah, juga menunjukkan bahwa wadah ini memiliki nilai yang sangat berharga, sehingga menuntut pemeliharaan yang seksama dan perlakuan hati-hati.

Hal ini memperjelas bahwa betapa pentingnya rumah bagi Orang Naga, dan karena itu pula hingga detik ini, mereka masih setia mengikuti aturan-aturan yang berlaku serta pola-pola yang telah diikuti sejak zaman dahulu. Patron atau pola bangunan tersebut bagi Orang Naga telah menjadi bagian dari sistem cara berpikir mereka, sehingga akhirnya menjadi sesuatu yang baku, seperti patokan terhadap tata ruang, bentuk, struktur bangunan, maupun ornamennya.

\section{C.1 Makna Simbolik dari Bentuk Rumah Naga}

Seorang wraga Kampung Naga, Mang Ardin yang ditemui menjelaskan bahwa salah satu tujuan sehingga rumah orang kampung Naga dibuat dalam bentuk panggung dan tiang-tiangnya diletakan di atas tatapakan adalah agar bahan bangunan yang digunakan seperti papan dan balok tidak mudah di makan rayap sehingga dapat bertahan lebih lama. Lebih lanjut Mang Ardin bertutur bahwa jika kayu sebagai bahan dasar sebuah bangunan langsung bersentuhan pada tanah, maka dalam waktu yang tidak terlalu lama kayu tersebut akan lapuk dan dimakan rayap, karena pada dasarnya, tidak ada kayu yang tahan terhadap rayap, jika tidak dipelihara. Salah cara untuk memelihara kayu/balok agar dapat bertahan lama adalah dengan jalan menempatkan kayu atau balok melayang di atas permukaan tanah. Ia juga menjelaskan bahwa kayu-kayu yang digunakan di Kampung Naga umumnya kayu biasa seperti kayu manglin dan alba (albasia: sengon). Karena kayu tersebut tidak bersentuhan langsung dengan tanah dan air, maka dapat bertahan lama.

Pilihan rumah panggung tidak dapat dielakkan dari pengaruh kondisi iklim tropis yang lembab. Kondisi ini memberikan isyarat bagi logika manusia untuk melakukan rekayasa rancang bangun rumah yang berorientasi pada perubahan musim sebagai akibat dari karakter lingkungan. Pilihan model rumah panggung dengan menggangkat lantai dari atas tanah memiliki dasar berpijak yang logis. Bentuk rumah panggung akan melindungi material bangunan dari kelembaban alam tropis yang dengan mudah membusukkan bahan yang bersifat organik. Selain itu, tipologi rumah panggung memungkinkan bagi terjadinya sirkulasi udara untuk bergerak bebas di bawah lantai, sehingga lantai lantai tidak menjadi lembab/basah, sekaligus menjadikan ruang yang berada di atasnya menjadi lebih kering. 
Selain apek-aspek logis yang disebutkan di atas, teknologi panggung pada bangunan rumah dimungkinkan untuk memberikan kehangatan pada penghuninya. Bagian kolong dari panggung tersebut bisa digunakan untuk menyimpan alat-alat pertanian atau kayu bakar. Bentuk panggung yang mendominasi sistem bangunan di Tatar Sunda mempunyai fungsi teknik dan simbolik. Secara teknik, rumah panggung memiliki 3 (tiga) fungsi 1) tidak mengganggu bidang resapan air; 2) kolong sebagai media pengkondisian ruang dengan mengalirnya udara secara silang baik untuk kehangatan (di malam hari) atau kesejukan (di siang hari); dan 3) dari fungsi, kolong juga dipakai untuk menyimpan persediaan kayu bakar dan lain sebagainya. .

Mulder sebagaimana yang dikutip oleh Koentjaraningrat, menyebutkan bahwa keberadaan konsep estetika sebagai wujud gagasan yang abstrak selalu dipengaruhi oleh pengalaman masing-masing individunya maupun pengalaman kolektif yang dialami kelompok masyarakat tertentu. Pengalaman ini meliputi pengembangan kepercayaan terhadap kekuasaan dan kekuatan yang lebih tinggi; hubungan sosial dengan orang atau kelompok lain; ekspresi kepribadian individual kepada lingkungan masyarakat di sekitarnya; mengupas makna-makna yang dapat diterima oleh lingkungan. ${ }^{8}$ Mengacu pada perspektif di atas, maka pada prinsipnya orientasi bangunan Kampung Naga yang berbentuk panggung, tidak semata-semata bertujuan sebagaimana yang diterangkan oleh Mang Ardin sebagaimana di atas. Penjelasan di atas memang memiliki makna logis, namun orientasi rumah dalam bentuk panggung seperti yang disaksikan di Kampung Naga tidak semata-mata berdiri di atas logika untuk memelihara ketahanan bahan yang rentan terhadap kelembaban dan seketika dapat terserang rayap, tetapi juga terkait dengan nilai-nilai kearifan lokal, bahkan faktor kepercayaan.

Ruang-ruang yang dibangun melayang diatas tanah pada rumah Kampung Naga, secara implisit adalah ungkapan kesadaran orang Naga yang merasa di atas dan mengatasi alam. Dalam bangunan tersebut mereka tinggal dan bernaung, yang secara simbolik bermakna bahwa Orang Naga tidak mau hanya menyentuh atau terlempar pada tingkat tanah (alam). Secara denotative, ungkapan tersebut merupakan ekspresi tentang harga diri orang Naga untuk mengatasi alam, (membendung diri dari sengatan sinar matahari, hempasan air hujan dan ancaman binatang buas). Namun pada saat yang sama, secara konotatif, pilihan bentuk rumah berdesain panggung, sekaligus merupakan ungkapan akan penghargaan terhadap alam, karena tidak menguasai dan mengesplitasi permukaan tanah secara serakah. Melalui simbol rumah panggung, Orang Naga seolah ingin menyatakan bahwa tanah

\footnotetext{
${ }^{7}$ Miharja: 1981: 89-90)

${ }^{8}$ Koentjaraninggrat, Pokok-Pokok.....h. 58
} 
yang mereka gunakan merupakan wadah untuk berpijak, tanpa harus menutupi seluruhnya, dan hal ini tentu saja menunjukan kearifan jiwa Orang Naga. Lebih lanjut dapat dijelaskan, bahwa pilihan rumah panggung merupakan paralelisme dari kosmologi orang Sunda yang membagi alam ke dalam tiga tingkatan, yaitu dunia atas, dunia dunia tengah dan dunia bawah.

Dengan demikian, fungsi simbolik rumah dalam konteks Orang Naga terkait erat dengan dasar kepercayaan warisan leluhur yang membagi dunia kedalam tiga tingkatan, yaitu dunia bawah, dunia tengah dan dunia atas. Dunia tengah merupakan epicentrum dari alam semesta, dan manusia menempatkan diri dalam pusaran epicentrum tersebut, karena itulah manusia dalam memilih ruang untuk kehidupannya memilih untuk berada di tengahtengah, bukan berada di dunia bawah (bumi) dan atas (langit). Dari makna simbolik ini, maka dalam struktur terdapat atau dibuat tiang yang berfungsi sebagai pemisah rumah secara keseluruhan dengan dunia bawah dan atas. Tiang rumah secara langsung menempel atau diletakkan di atas tanah, oleh karena itu harus diberi alas yang berfungsi memisahkannya dari tanah, yaitu berupa batu yang disebut umpak atau tatapakan. Dengan demikian pilihan rumah panggung oleh Orang Naga selain memiliki dasar-dasar logis dan rasional, juga sangat terkait dengan penerapan ideologi yang berbasis pada kepercayaan leluhur.

\section{C.2 Makna Simbolik Ruang}

Sebagai masyarakat religius, rumah Orang Naga memiliki dimensi sakralitas, seperti struktur panggung. Bentuk ini memiliki hubungan dengan kepercayaan leluhur, yang mengaitkannya dengan kekuatan alam yang berpusat pada dunia atas dan dunia bawah. Oleh karena itu, struktur-nya tidak boleh menyentuh tanah. Demikian pula dengan ruang, masyarakat Naga membagi ruang yang disesuaikan dengan masing-masing fungsinya yang berbasis pada kepercayaan dan keyakinan mereka. Pembagian ini dibagi berdasarkan jenis kelamin dan urutan keluarga.

Oleh karena itu, organisasi ruang pada Rumah Naga pada prinsipnya tidak dapat dilepaskan dengan kepercayaan masyarakat agraris, seperti masyarakat pada umumnya. Meletakan ruang tidak lepas dari dasar kepercayaan mereka yang hormat terhadap alam/menghargai alam. Jiwa orang Naga adalah jiwa manusia petani yang mendasari organisasi ruangnya pada pembentukan ruang yang selaras dan logis. Hal ini merupakan perpaduan antara demensi-demensi religius dengan pandangan realistis dan teknis praktis, serta materi. Susunan ruang memperlihatkan jiwa sang petani, yang terbagi ke dalam pembagian yang bersifat privat (intim) dan sakral disebut "goah", serta bagian luar yang sebut emper. Ruang emper sebagai pelataran yang diperuntukkan bagi umum, tempat anak-anak bermain, untuk 
perjamuan, dan terkadang juga digunakan sebagai ruang pertemuan antara penghuni rumah dan masyarakat. Goah sebagai ruang sakral dipakai untuk melakukan upacara inisiasi serta tempat bersemayamnya Dewi Sri. Meski demikian fungsi "goah" selain sebagai media penghubung antara penghuni rumah dengan Dewi Sri, juga dapat dimaknai sebagai simbolisasi kedaulatan pangan.

Dengan demikian, seluruh tatanan ruang selalu berhubungan dengan nilai budaya yang mereka warisi dari tradisi atau adat leluhur sekaligus terkait dengan dasar-dasar kepercayaan. Wilayah dalam dan luar, antara keterbukaan bermasyarakat dan ketertutupan (keintiman tertutup) keluarga memperoleh suatu kesatuan yang harmonis dan dialektik luar-dalam antara hidup pribadi dan kemasyarakatan tercapai sangat seimbang. Begitu juga penataan goah yang sakral dan emper yang profane, menunjukan pada terciptanya kesatupaduan serasi antara hubungan vertikal ke Kuasa Yang Supra dan horisontal ke sesama makhluk atau insan.

\section{C.3 Dapur sebagai Ruang Sakral}

Tidak seperti kebanyakan dapur dalam desain rumah pada umumnya, ruang dapur Orang Kampung Naga berada di bagian depan, sejajar dengan atau bersebelahan dengan ruang tamu. Hal ini sama dengan tata letak dapur pada rumah Orang Kajang Bulukumba Sulawesi Selatan, yang juga berada di depan. Dugaan awal bahwa boleh jadi kandungan filosofi dapur antara Orang Naga dengan orang Kajang memiliki kemiripan. Seorang warga Kampung Naga, Mang Tanu menjelaskan bahwa pintu dan dinding dapur Orang Naga terbuat dari anyaman bambu atau rotan yang berbentuk "sasag". Ini bermakna agar orang dari dalam dapat melihat orang atau tetangga yang berada di depan, tetapi orang dari luar tidak dapat melihat ke dalam. Fungsinya adalah agar antar tetangga dapat saling memperhatikan, saling bantu membantu, saling asah, asih dan asuh seperti ajaran leluhur. Dengan menggunakan dinding "sasag", maka asap dapur dapat dengan mudah keluar. ${ }^{9}$

Dalam kehidupan sehari-hari, dapur adalah bagian kosa kata yang akrab terdengar di telinga, yang secara defenitif biasa dimaknai sebagai tempat dimana aktivitas masak-memasak dilakukan. Sehingga ketika mendengar kata dapur, biasa disimbolkan sebagai pusat "kehidupan", karena makanan sebagai penyuplai energi ke dalam tubuh, dimana pembuatan dan pengelolaannya berawal dari dapur. Secara khusus, dapur adalah tempat atau ruang dimana wanita atau perempuan Naga beraktivitas. Pembagian kerja menurut jenis kelamin ini tidaklah mengejutkan, memasak khususnya menanak nasi berhubungan erat dengan ritual wanita. Namun demikian, yang

\footnotetext{
${ }^{9}$ Mang Tanu, wawancara
} 
lebih penting adalah posisi dapur yang tidak hanya sekedar tempat untuk memasak bagi seorang wanita, tetapi adanya keyakinan yang tertanam dibalik fisik bangunan dapur tersebut. Dapur sebagai tempat memasak dalam konteks orang Naga juga diasosiasikan dengan Dewi Sri. Menurut kepercayaan mereka, Nyi Pohaci Sangiang Sri Dandayang Tisnawati (Dewi Sri) adalah pengayom tanaman padi.

Tampaknya peletakan goah di dalam pawon tidaklah berdiri sendiri, tetapi didasarkan atas keyakinan dan penghormatan terhadap Dewi Sri. Goah diletakkan sebelah barat atau timur sesuai dengan weton atau hari kelahiran isteri. Di dalam goah diletakkan sesaji untuk Dewi Sri setiap hari Selasa dan Jum'at. Sesaji dalam goah terdiri atas rujakan yang berisi gula merah, kelapa dan air dalam gelas. Rujakan ini diletakkan di atas kendi dan satunya lagi di atas padi.

Dengan demikian, fungsi goah selain sebagai ruang bercengkrama antara ibu-ibu dan perempuan kampung serta untuk menyimpan dan meletakkan peralatan dapur, juga memiliki fungsi sakral. Sakralitas dari wilayah ini karena dipakai untuk melakukan ritual pribadi, seperti semedi atau tirakat dengan cara membakar kemenyan. Ritual ini bertujuan untuk menghadirkan roh karuhun (leluhur) untuk berbagai macam kepentingan. Ritual yang dilakukan di padaringan terlihat pada saat wanita menyimpan padi, yaitu meletakkan gelas yang berisi air putih, diletakkan di samping pabeasan dengan dibacakan beberapa jangjawokan (mantera-mantera), agar Nyi Pohaci Sanghyang Sri (Dewi Padi) memberi restu dan memberikan berkah. Dengan demikian, fungsi sosial secara tidak langsung menjadi cara bagi masyarakat Naga dalam menjaga hubungan silaturahmi antar sesamanya. Sedangkan fungsi ritual merupakan upaya untuk menjaga keseimbangan dalam menjalin hubungan dua dunia yang berbeda, agar harmonis, antara yang kasat mata dengan yang tidak kasat mata.

\section{C.4 Nilai Dan Norma Budaya Dalam Simbol Rumah Naga}

Terdapat sejumlah perlambangan yang tertanam dalam "simbolisasi kultur", rumah Orang Naga yang dapat diindentifikasi pada perwujudan fisik rumah tradisional Kampung Naga dalam tinjauan generalis, sebagaimana akan diuraikan berikut.

a. Elemen elemen yang membentuk

Konstruksi rumah Kampung Naga secara keseluruhan dapat dibedakkan atas tiga bagian utama, masing-masing adalah bagian atap (kepala), bagian badan dan bagian kolong (kaki). Bagian atap diidentikkan dengan dunia atas atau perlambangan kuasa adikodarti (Tuhan) - yang diyakini bahwa dunia ini adalah dunia yang paling suci. Bagian badan rumah disinkronkan dengan dunia manusia, karena memang pada bagian ini manusia 
melakukan segala aktivitasnya. Bagian kolong diidentikkan sebagai dunia bawah.

b. Tata letak dan orientasi bangunan

Bangunan rumah yang seluruhnya mengarah ke utara-selatan, secara implisit menunjukkan pada pola bangunan sistem sosial dan budaya yang demokratis. Kondisi ini juga tampak nyata pada wujud rumah-rumah Orang Naga yang seragam, tidak ada yang menonjol secara khusus sebagaimana yang biasanya hadir pada lingkup komunitas masyarakat yang feodalistis.

d.Status dan kedudukan sosial

Sekalipun tidak direduksi bahkan memiliki peran secara adat yang sangat menentukan, namun status sosial Orang Naga tidak hadir dalam bentuk bangunan. Antara rumah seorang kuncen, lebe maupun punduh tidak memiliki perbedaan yang signifikan dengan warga lainnya.

e. Penggunaan ornamen dan ragam hias yang relatif kurang

Ornamen dan ragam rias yang kurang semakin mempertegas karakteristik dan tipologi Orang Kampung Naga yang bersahaja dan cenderung lebih fokus pada persoalan-persoalan kehidupan yang praktis. Dominasi corak ragam hias yang bersumber dari bentuk-bentuk alamiah (flora dan fauna), seperti anyaman bambu berbentuk "sasag" juga menunjukkan pada apresiasi masyarakat Kampung Naga terhadap lingkungan fisik alamiahnya yang dipandang sebagai berkah terindah dari warisan leluhur yang harus dipelihara dan dilestarikan.

f. Pola penataan fasade

Bagian depan bangunan yang setangkup (simetris) juga menyiratkan karakteristik masyarakat Kampung Naga yang mengutamakan kepraktisan dan idealisme. Pola simetris merupakan simbolisasi norma "kesetaraan" atau "kejujuran" yang dijunjung tinggi dan diwariskan dari generasi ke generasi oleh masyarakat Kampung Naga, sekaligus merupakan simbol norma yang demokratis.

g. Perwujudan beranda depan atau "golodog" yang bersifat publik

hal ini merupakan simbol dari norma kultur dan sosial Orang Naga yang "terbuka" dan menjunjung tinggi silaturrahim serta hubungan kekerabatan dan kemasyarakatan. Secara keseluruhan kandungan perlambangan yang disebutkan di atas, mengisyaratkan berbagai dimensi kultural masyarakat Kampung Naga, baik dalam tataran nilai, norma, ataupun gagasan hingga tataran sistem aktivitas. ${ }^{10}$

${ }^{10}$ Rogi, Octavianus Hendrik Alexander \& Siswanto, Wahyudi, "Identifikasi Aspek Simbol Dan Norma Kultural Pada Arsitektur Rumah Tradisional Di Minahasa", Jurnal EKOTON Vol. 9, No.1 (April, 2009): 43-58. 


\section{MEMBACA RUMAH NAGA DARI SUDUT PANDANG ARSITEKTUR ISLAM}

Arsitektur Islam adalah cara membangun yang Islami sebagaimana ditentukan oleh hukum syariah, tanpa batasan terhadap tempat dan fungsi bangunan, namun lebih kepada karakter Islaminya dalam hubungannya dengan desain bentuk dan dekorasi. ${ }^{11}$ Dengan demikian, arsitektur Islam merupakan salah satu gaya arsitektur yang menampilkan keindahan yang kaya akan makna. Setiap detailnya mengandung unsur simbolisme dengan makna yang sangat dalam. Lebih jauh, arsitektur Islam lebih mengusung pada nilai-nilai universal yang dimuat oleh ajaran Islam. Nilai-nilai ini nantinya dapat diterjemahkan ke dalam bahasa arsitektur dan tampil dalam berbagai bentuk tergantung konteksnya, dengan tidak melupakan esensi dari arsitektur itu sendiri, serta tetap berpegang pada tujuan utama proses berarsitektur, yaitu sebagai bagian dari beribadah kepada Allah. ${ }^{12}$

Arsitektur Naga, sebagaimana yang telah dijelaskan sebelumnya berkait erat dengan tradisi masa lalu atau leluhur mereka yang dalam beberapa segi masih merupakan paralelisme dari zaman Hindu, seperti simbolisme rumah panggung yang mengacu pada kosmologi dunia atas, tengah dan bawah. Namun demikian banyak hal dalam pembagian tata ruang Rumah Naga, yang secara jujur dapat dinyatakan sebagai sesuatu yang Islami. Identifikasi atas disain interior Rumah Naga secara jelas dapat dilihat dalam penciptaan berbagai bilik ruang yang disebut tepas, tengah imah, pangken, juga menunjukkan pengaruh serupa. Ruangan-ruangan yang disebutkan tersebut berfungsi sebagai pembatas atau sebagai tanda kejelasan fungsi ruangan dalam satu bangunan yang meliputi ruang tamu, ruang keluarga, dan ruang khusus anak.

Adanya pembatas ruangan yang memisahkan antara ruangan lawan jenis, khususnya ruang anak gadis, secara mendasar memiliki kesesuaian dengan nilai-nilai Islam. Ajaran Islam normatif, menetapkan norma hubungan antara remaja puteri dan putera secara ketat atau minimal tidak sebebas cara pandang Barat dalam mengatur hubungan antara pria dan wanita.

Meskipun pada awalnya penataan ruang pemisah dan pembatas antara ruang privat dan umum bukanlah merupakan imbas langsung dari ajaran Islam, tetapi secara mendasar desain tata ruang tersebut dalam batas-batas tertentu dapat dinyatakan sebagai sesuatu yang berdimensi Islami, mengingat

\footnotetext{
${ }^{11}$ Saoud, 2002, h. 2

12 Yahya, Aulia, Arsitektur Islam: Seni Ruang dalam Peradaban Islam, Makalah, 2012.
} 
kultur dan tradisi normatif Islam yang berbasis pada pemahaman pentingnya memelihara aurat seorang wanita yang tidak layak untuk dilihat kecuali oleh para muhrimnya.

Pada sisi lain, dalam organisasi ruang Rumah Naga juga masih ditemukan adanya ruang yang secara empiris hingga kini perwujudan dan peruntukannya secara eksplisit terkait erat dengan ritus yang didasarkan atas kepercayaan yang berbasis pada keyakinan Hindu. Hal tersebut dapat dilihat pada keberadaan goah yang dari segi fungsi dan praktek penggunaannya secara empiris masih bertahan hingga sekarang, yaitu sebagai sarana untuk "beribadah". Disain goah yang peruntukannya sebagai sarana ritual seperti yang telah dijelaskan memang perlu untuk mendapat catatan pinggir, bila kita ingin meninjaunya dari sudut pandang arsitektur Islam. Oleh karena itu, terkait dengan kasus goah, maka agak sulit untuk meletakkannya kedalam jenis desain arsitektur yang pemaknaannya berada pada ruang arsitektur Islami. Hal ini sangat berbeda dengan konsep pembagian ruang yang didasarkan atas klasifikasi gender, yang secara sadar atau tidak acuan legitimasinya dapat dirujuk pada basis ajaran Islam.

Dalam konteks tersebut di atas, maka sistem sosial budaya masyarakat Naga yang mewujud pada bentuk dan organisasi ruang Rumah Naga, sesungguhnya merupakan kesatuan organik berbagai unsur yang berasal dari dalam masyarakat Naga sendiri maupun yang datang dari luar, sekaligus merupakan implikasi dari pengaruh perjalanan masa yang mengelilingi mereka. Meskipun pengaruh budaya asing (dari luar masyarakat Naga) terhadap budaya masyarakat setempat terjadi, namun hubungan antar unsur tersebut membentuk suatu perpaduan yang dinamis. Hal ini terjadi sebagai akibat dari proses interkasi antar unsur yang saling menyapa satu dan yang lainnya, sehingga dalam proses tersebut terjadi upaya penerimaan, penyesuaian dan pemadanan antar unsur budaya setempat dengan yang datang dari luar, tanpa harus melahirkan "konflik" yang berarti.

Penyesuaian dan perpaduan antar unsur budaya seperti yang dijelaskan adalah suatu kondisi yang lumrah dan wajar terjadi, oleh karena secara alami setiap unsur baru yang masuk dalam sebuah ruang budaya, niscaya untuk beradaptasi dengan seluruh sistem yang telah terbentuk lebih awal, minimal dengan dasar-dasar nilai yang terdapat dalam satu ruang budaya sebelum muncul, sebagai satu bagian dari unsur budaya setempat. Salah satu realitas yang tak terhindarkan oleh komunitas manapun termasuk Orang Naga adalah magnet dari gaya gravitasi bumi yang setiap saat menggiring individu maupun sebuah komunitas untuk melakukan pengolahan terhadap normativitas teks ke ranah yang lebih sesuai dengan pandanganpandangan dunia baru dan disesuaikan dengan alam lingkungan budaya yang 
lagi in. Kondisi tersebut, disadari atau tidak telah terjadi dalam ruang budaya Orang Naga, meskipun hal tersebut boleh jadi masih bersifat individual.

Upaya melakukan reintrepretasi terhadap simbol-simbol yang tertanam dalam teks budaya Orang Naga oleh Orang Naga, pada prinsipnya kini sedang berjalan. Oleh karena itu, tidak berlebihan untuk dinyatakan dinamika sosial budaya yang kini sedang terjadi dalam lingkungan Kampung Naga salah satu bentuknya adalah terjadinya upaya oleh masyarakat terkait atau dari orang per orang untuk mencoba memahami beberapa simbol yang tertuang dalam teks rumah Naga sebagai bentuk pengejawantahan nilai-nilai Islami. Misalnya, pemaknaan Mang Jabal mengenai arah suhunan atau kap rumah yang berorientasi ke Barat. Meskipun tidak secara eksplisit ingin menyebutkan bahwa orientasi tersebut berpijak pada nilai-nilai Islam, namun secara tersirat Mang Jabal menyatakan hal tersebut dengan ungkapan; "seluruh bangunan menghadap Utara atau Selatan, dan seluruh rangka atap depan (pangaret) menghadap qiblat (barat)". ${ }^{13}$

Interpretasi tersebut, jelas merupakan upaya kreatif Mang Jaabal dalam memaknai simbol Rumah Naga sebagai sesuatu yang berasal dari perwujudan etik orang Naga yang selalu mengarahkan hidupnya ke Qiblat, meskipun akar sejarahnya boleh jadi orientasi tersebut pada awalnya bukanlah ditujukan untuk mengarakan orientasi bumbungan rumah Naga kearah Qiblat tetapi ke bumi ageung. Jika ditelisik lebih dalam lagi, maka pemaknaan tersebut terjadi karena subyek yang memaknai simbol tersebut dalam hal ini adalah Mang Jabal, yang memiliki latar pendidikan santri, sehingga terjadi perubahan orientasi pemaknaan. Dari sisi ini, ada dugaan jika Mang Jabal yang secara struktural memegang jabatan sebagai pengurus masjid yang sehari-harinya juga bertugas mendidik anak-anak TPA serta memberikan pengajian sekali sebulan, sedang memainkan peran "Islamisasi".

Pemaknaan dan pengaitan simbol fisik yang dahulunya memiliki makna simbolik yang berbasis pada ajaran luar Islam kemudian diintrepretasi ke dalam pemaknaan yang berkarakter kultur Islam, bukanlah hal baru, dalam tradisi Muslim di Indonesia. Contoh yang paling dekat untuk kasus ini, dapat dilihat pada interpretasi atap masjid, baik yang berundak tiga ataupun lima. Atap yang berundak tiga oleh kalangan muslim dimaknai sebagai simbol dari tingkatan cara beragama yaitu: syariat, makrifat, dan hakikat. Sedangkan simbol atap berundak lima adalah simbolisasi dari rukun Islam.

Sebagai sebuah keniscayaan, dapat dinyatakan bahwa proses hubungan yang dialektis dan timbal balik antara agama dan budaya lokal merupakan fenomena umum yang terjadi di mana-mana, sehingga apa yang terjadi pada Orang Naga dapat dinyatakan sebagai hal yang lumrah. Sejalan

${ }^{13}$ Mang Jaabal, wawancara 
dengan pandangan di atas M. Amin Abdullah menyatakan, bahwa dalam banyak hal, penyimpangan-penyimpangan atau kelainan-kelainan lokal yang terjadi pada pengamalan Islam di suatu daerah berfungsi sama dengan agamaagama yang tidak memiliki tradisi tulis. Namun pada saat yang sama tradisitradisi lokal tersebut juga secara terus-menerus dipengaruhi dan ditentukan oleh tradisi-tradisi besar yang bersumber dari agama yang sama. ${ }^{14}$

Pengaruh yang berlangsung secara berkesinambungan oleh tradisi besar (Islam) terhadap budaya lokal, seperti yang disebutkan oleh Abdullah, juga tarjadi di Orang Naga Dalam konteks hubungan Islam dengan tradisi lokal Orang Naga, dapat dilihat pada akar sejarah basis keyakinan tentang orientasi arah suhunan jolopong yang mengambil posisi Timur-Barat. Bagimanapun juga, pilihan arah dan orientasi tersebut pada mulanya merupakan ajaran yang bersumber dari tradisi leluhur atau simbolisasi penghormatan terhadap bumi ageung. Ajaran yang semula merupakan tradisi leluhur tersebut, selanjutnya diproses dalam ruang sejarah sehingga terjadi konfigurasi warna atau motif. Warna atau basis kosmologi yang semula "murni" berasal dari konsep penghormatan terhadap leluhur diberi corak "Islam", yaitu dengan jalan meligitimasi konsep tersebut dengan simbolsimbol Islam, dalam hal ini Qiblat (baitullah Makkah al-Mukarram).

Secara empirik pada masyarakat ini masih hidup berbagai kepercayaan masa lalu yang melekat dalam tradisi kehidupan mereka (masyarakat Orang Naga). Kesannya "melenceng" dari konsepsi tauhid, namun hal itu bukan alasan untuk menjauhkan mereka dari kata Islam, seperti yang banyak dilontarkan oleh para pengamat. Bentuk-bentuk pengamalan keyakinan yang terjadi dalam suatu komunitas bersifat historis atau terus berproses dalam ruang budaya sejarah, maka ke depan terbuka peluang yang lebar bagi terjadinya titik balik dalam aspek keyakinan, khususnya keyakinan kepada Dewi Sri. Apalagi Orang Naga yang berada dalam ruang sejarah bukanlah masyarakat yang pasif. Beranjak dari analisa yang dibentangkan, dapat dinyatakan bahwa realitas bingkai Islam dalam kearifan lokal pada masyarakat Naga, menunjukkan pada terjadinya hubungan dinamis yang menyebabkan terjadinya perubahan konsep dasar atau motif-motif pada beberapa budaya lokal. Perubahan itu terjadi sebagai akibat masuknya tradisi Islam ke dalam ruang budaya masyarakat Naga. Umumnya perubahan terjadi secara perlahan-lahan dan sangat dipengaruhi oleh suasana lingkungan sosial budaya masyarakat Naga yang terus berkembang.

Dengan demikian, proses interaksi antara Islam dengan budaya lokal yang terjadi pada masyarakat Naga, dapat dinyatakan sebagai hubungan dinamis dan berlangsung secara harmonis dan telah menyebabkan tradisi

${ }^{14}$ Abdullah dalam Zakiuddin, 2003, xviii-xix 
setempat yang genuine berubah menjadi tradisi Islam lokal. Hubungan dialektik yang terjadi antara Islam dengan budaya lokal telah mengarahkan tradisi lokal Orang Naga menjadi tradisi Islam lokal. Hal tersebut selain disebabkan oleh faktor-faktor dinamika sosial budaya yang berlangsung sejak awal mula Islam dicanangkan di wilayah ini, juga tidak lepas dari andil institusi keagamaan, pemuka agama, organisasi sosial keagamaan, demikian pula dengan berbagai institusi pendidikan Islam yang tumbuh dan berkembang di sekitar wilayah Kampung Naga, seperti Pondok Pesantren AlAmanah Neglasari.

\section{PENUTUP}

Bentuk Rumah Naga memiliki makna estetika yang terkait dengan kepercayaan adanya dunia atas, dunia tengah dan dunia bawah. Bentuk komposisi ruang Rumah Naga masih dipercaya untuk penempatan ruang perempuan dan laki-laki, selain terdapat ruang netral dan ruang sakral. Bagi Orang Naga, rumah memiliki makna dan nilai yang sangat berharga, sehingga menuntut pemeliharaan yang seksama dan perlakuan hati-hati. Oleh karena itu hingga detik ini, mereka masih setia mengikuti aturan-aturan yang berlaku serta pola-pola yang telah diikuti sejak zaman dahulu. Patron tersebut telah menjadi bagian dari sistem cara berpikir mereka. Dalam perkembangan selanjutnya, tampak ada upaya dari internal Orang Naga untuk memberi perspektif baru dalam memaknai Rumah Naga, yang mengarah pada intrepretasi yang berorientasi pada nilai-nilai Islam. Misalnya, orientasi suhunan jolopong yang mengahadap ke Barat, dipandang sebagai perwujudan etik Orang Naga yang selalu mengarahkan hidupnya ke Qiblat.

Garis besar isyarat yang termanifestasi dalam wujud arsitektur Rumah Naga, merupakan artikulasi dari simbol yang terbentang, dari gagasan spiritual tentang konsep Ketuhanan, gagasan spiritual tentang eksistensi "dunia bawah" yang metafisis sifatnya, serta keselarasan hubungan antara sesama manusia dan manusia dengan alam. Simbol-simbol yang tertanam dalam Rumah Naga, merupakan gambaran dari gagasan mengenai sistem kemasyarakatan yang demokratis. Dimana status dan kedudukan sosial sekalipun tidak direduksi, namun status tersebut tidak hadir dalam bentuk bangunan. Rumah Naga juga merupakan simbolisasi sistem tata laku yang menjunjung tinggi kebersamaan, dinamis dan terbuka terhadap kontak budaya, tetapi tetap konsisten dengan adat leluhur. Kumpulan simbol yang tertanam dalam Rumah Naga, pada prinsipnya memiliki nilai-nilai universal, kecuali simbolisasi goah yang dipercayai sebagai ruang Dewi Sri, namun dalam banyak hal desain bentuk dan tata ruang Rumah Naga memiliki kesesuaian dengan nilai arsitektur Islam, sehingga Rumah Naga dalam batas- 
batas tertentu dapat dinyatakan sebagai potret Islam dalam bingkai kearifan lokal.

\section{DAFTAR PUSTAKA}

Barliana, Syaom. "Perkembangan Arsitektur Mesjid: Suatu Transformasi Bentuk dan Ruang", Jurnal Historia, Vol IX, No.2 (Desembar, 2008)

Deny, Martinus. "Rumah Tradisional Sunda dalam Perspektif Teori Paradoks". Makalah, 2009.

Dewi, Indiriana Kusuma dan Priono Sujiono. "Penggambaran dalam Sistem terhadap Faktor- faktor Penentu Emisi $\mathrm{co}_{2}$ pada Pembangunan Rumah dan Kehidupan di Kampung Naga". Jurnal Lingkungan Tropis, Edisi Khusus Agustus 2007.

Dewi, Ni Ketut Agusinta. "Wantah Geometri, Simetri, dan Religiusitas Pada Rumah Tinggal Tradisional Di Indonesia”. Jurnal Permukiman "Natah", Vol. 1 No.1 (Februari, 2008)

Eppy, dkk. Estetika Bentuk. Jakarta; Gunadarma, 1986.

Hidayatun, Maria. Hakekat Ruang dalam Arsitektur Tradisional sebagai Satu Bentuk Jawaban dari Tantangan Alam (Studi Arsitektur Tradisional Arsitektur). Surabaya: FT Petra, 2008.

Jamaluddin. "Memahami Desain Dan Arsitektur Tradisional Sunda". Makalah pada Pelatihan Penelitian Ethnografi, 2012.

Koentjaraningrat. Pokok-Pokok Antropologi Sosial. Jakarta: Dian Press, 1985.

Nuryanto dan Isep Machpudin. "Kajian Pola Kampung dan Rumah Tinggal Warga Kasepuhan Kesatuan Adat Banten Kidul di Sukabumi SelatanJawa Barat". Artikel Hasil Penelitian dan Pengembangan Departemen Pendidikan Nasional Tahun Anggaran/ UPI 2007.

Raharjo, Mudjia. Hermeneutika Gadamerian. UIN-Malang Press, Malang, 2007.

. Dasar-Dasar Hermeneutika antara Intersionalisme dan Gadamerian. Ar-Ruzmedia: Yogjakarta, 2008.

Rogi, Octavianus Hendrik Alexander \& Siswanto, Wahyudi. "Identifikasi Aspek Simbol Dan Norma Kultural Pada Arsitektur Rumah Tradisional Di Minahasa". Jurnal EKOTON Vol. 9, No.1 (April, 2009): 43-58.

Sahroni, Ade. Arsitektur Vernakular Indonesia: Peran, Fungsi, Dan Pelestarian Di Dalam Masyarakat. Makalah 19 Maret 2012, Puslitbang Arkenas,

Saringendyanti, Etty. Kampung Naga, Tasikmalaya Dalam Mitologi: Upaya Memaknai Warisan Budaya Sunda. Laporan Penelitian pada Jurusan Ilmu Sejarah Fakultas Satra Universitas Padjadjaran, 2008. 
Wahyudi, Agung. "Perancangan Bangunan Tradisional Sunda sebagai Pendekatan Kearifan Lokal, Ramah Lingkungan dan Hemat Energi". Jurnal Lokal Wisdom, Vol. II, No.1 (2010)

Wiranto. "Arsitektur Vernakular Indonesia: Perannya Dalam Pengembangan Jati Diri.dalam Jurnal Dimensi Teknik Arsitektur”. Vol. 27, No. 2, (Desember 1999): 15-20.

Yahya, Aulia. "Arsitektur Islam: Seni Ruang dalam Peradaban Islam”. https://auliayahya.wordpress.com/2008/11/04/arsitektur-islam-seniruang-dalam-peradaban-islam/. Diakses tanggal 14 Februari 2016 